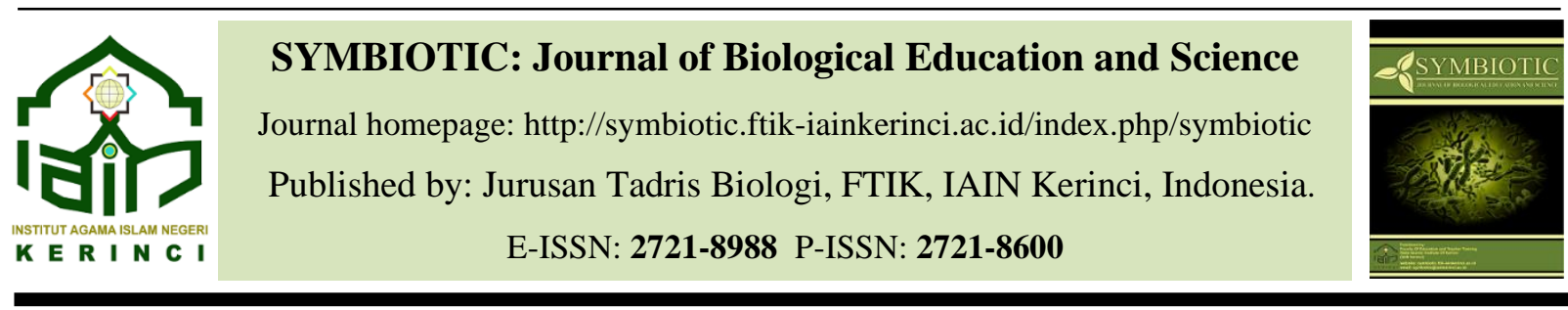

\title{
Pengembangan Buku Bergambar Bertekstur Dilengkapi Teka-Teki Silang Sebagai Media Pembelajaran Biologi Materi Jaringan Epitel Kelas XI SMA
}

\author{
Fima Diah Rovvy Anggraeni', Siti Mukhlishoh ${ }^{2}$, Saifullah Hidayat $^{3}$ \\ ${ }_{1,2,3}$ Pendidikan Biologi Fakultas Sains dan Teknologi \\ UIN Walisongo Semarang Jl. Prof. Dr. Hamka Kampus II Ngaliyan \\ Email Korespondensi : hidayatsaifullah@walisongo.ac.id
}

\begin{abstract}
Media is one of tool to help the learning process. The media used in Senior Hight School 7 Semarang still general like book and LKS, the media admitted still has weakness from the presentation of contents, picture and increasing students interest, so that the learning looks monotonic and less to give progress of learning which is fun in the class.This research was conducted to develop the science book media with ephitel tissue as sub topic. This research uses the method. $(R \& D)$ with 4-D development model Thiagarajan dkk production Defind, Design, Develop and Dessiminate. The result of the research is based on the assessment of media material expert has decent criteria (Very Good) with $90.9 \%$ percentage, assessment according to the media expert is included in the criteria worth (excellent) with $85.5 \%$ percentage and the assessment according to the teacher is included in the appropriate category (Very Good) with a percentage of $98.48 \%$. The effectiveness of the media on the value of entry in the category is quite effective with the mean of the average student control score of 5.70. Media readability test after using in the learning category is very good with a percentage of $86.1 \%$. The result of reseach showing deserves using in the learning.
\end{abstract}

Keyword: Developing media, Pictures and Textured Book, Media Learning, Materials Ephitel

\begin{abstract}
ABSTRAK
Media merupakan salah satu alat untuk menunjang proses pembelajaran. Media yang digunakan di SMA N 7 Semarang masih monoton berupa buku dan LKS konvensional. Media yang ada dianggap masih memiliki kelemahan dari segi penyajian isi, gambar dan meningkatkan minat siswa, sehingga pembelajaran terkesan monoton dan kurang menunjang pembelajaran yang menyenangkan di kelas. Penelitian ini bertujuan untuk melakukan pengembangan terhadap media buku dengan sub materi jaringan epitel. Penelitian ini menggunakan metode Reseach and Development $(R \& D)$ dengan model pengembangan 4-D Thiagarajan dkk meliputi Define, Design, Develop dan Dessiminate. Hasil penelitian mendapatkan presentase 90,9\% d memiliki kriteria layak (Sangat Baik) dinilai oleh ahli materi, penilaian menurut ahli media masuk dalam kriteria layak (Sangat Baik) dengan presentase 85,5\% dan penilaian menurut guru pengajar masuk dalam kategori layak (Sangat Baik) dengan presentase 98,48\%. Keefektifan media terhadap nilai siswa masuk dalam kategori cukup efektif dengan rata-rata nilai siswa uji coba 6,77 dibandingkan dengan rata-rata nilai siswa kontrol 5,70. Uji keterbacaan media setelah penggunaan dalam pembelajaran masuk dalam kategori sangat baik dengan presentase 86,1\%. Hasil penelitian menunjukkan Media Buku bergambar Bertekstur Dilengkapi Teka Teki Silang Sub Materi Jaringan Epitel Kelas XI Semester 1 di SMA Negeri 7 Semarang dapat dikatakan layak digunakan.
\end{abstract}

Kata Kunci : Pengembangan media, Buku bergambar bertekstur, Bahan ajar, Materi jaringan epitel 


\section{PENDAHULUAN}

Materi Biologi dianggap sulit oleh mayoritas siswa khususnya dalam memahami istilah-istilah dan konsep biologi. Berdasarkan kegiatan Hasil belajar siswa materi jaringan epitel selama kegiatan Praktek Pengalaman Lapangan di SMA Negeri 7 Semarang kelas XI MIA 3 dengan jumlah siswa sebanyak 38 pada materi ini menunjukan poin 5 atau sempurna pada soal jarinngan epitel hanya didapatkan oleh satu siswa, sedangkan $30 \%$ siswa mendapatkan poin $4,50 \%$ siswa mendapatkan poin 2-3 dan sisanya mendapatkan poin 1 dan 0 . Data nilai rata-rata ulangan siswa sebesar 84,6 dengan siswa remidial sebanyak 11. Ibu Dra. Siti Nurjanah menjelaskan nilai KKM yang diterapkan di SMA N 7 Semarang untuk mata pelajaran biologi adalah 75.

Proses pendidikan harus mampu membentuk manusia utuh yang siap menghadapi dunia yang penuh tantangan dan cepat berubah, Guru harus memilih strategi serta media yang tepat dalam proses pembelajaran (Ali, 2007; Ferry, 2019) Pendukung tercapainya nilai siswa dalam ulangan salah satunya merupakan penggunaan media yang sesuai materi ajar. (Wawancara, September 2016). Pendapat tersebut sesuai dengan Hamalik (1994) yang mengungkapkan penggunaan media pembelajaran dapat meningkatkan keinginan dan minat baru, membangkitkan rangsangan dan motivasi kegiatan belajar, dan bahkan membawa pengaruh psikologis terhadap siswa.

Menurut Azhar Arsyad (2009) "kata media berasal dalam bahasa Latin yang berarti Medius yang secara harfiah berarti 'tengah', 'perantara', atau 'pengantar'. Dalam bahasa Arab, media adalah perantara atau pengantar pesan dari pengirim kepada penerima pesan. Media merupakan salah satu jenis dari sumber belajar yang memerlukan guru sebagaii mediatornya Dale (1969) dalam Sitepu (2014) mengungkapkan secara singkat, sumber belajar dapat dirumuskan sebagai suatu yang dapat dipergunakan untuk mendukung dan memudahkan terjadinya proses belajar. Pendapat lain tentang sumber belajar dikemukakan oleh AECT (Assosiasion of Educational and Communication Teachnology), (1997) yaitu "sumber baik berupa data, orang atau wujud tertentu yang dapat digunakan siswa dalam belajar, baik secara terpisah maupun terkombinasi sehingga mempermudah siswa dalam mencapai tujuan belajar."

Penggunaan media berupa buku bergambar tidak akan lepas kaitannya dengan gambar ilustrasi yang dituangkan didalamnya, pengertian ilustrasi sendiri menurut Joneta Witabora (2012) berasal dari kata Ilustrasi berasal dari kata latin illustrare yang berarti menerangi atau memurnikan pengertian ilustrasi sendiri adalah citra yang dibentuk untuk memperjelas suatu informasi dengan memberi presentasi secara visual. Gambar merupakan salah satu alternatif yang cukup digemari oleh siswa karena mirip dengan komik sehingga dapat meningkatkan minat belajar siswa. Salah satu jenis buku bergambar yang sesuai digunakan adalah buku bergambar bertektur yang masuk dalam kategori buku konsep ditinjau dari isi buku bergambar dan jenisnya menurut Rothlein dan Meinbach (1991) dalam Hari Santoso (2008). Tekstur yang terdapat dalam gambar ilustrasi media bertujuan untuk lebih memudahkan pemahaman siswa bukan hanya menggunakan indra penglihata namun juga menggunakan indra peraba, Yunus (1942:78) dalam bukunya Attarbiyatu watta'alim yang dikutip oleh 
Azhar Arsyad (2009)" mengungkapkan bahwasanya media pembelajaran paling besar pengaruhnya bagi indera dan dapat menjamin pemahaman". Yunus juga mengungkapkan orang yang hanya mendengarkan materi berbeda tingkat pemahaman dan lama bertahan pemahamannya jika dibandingkan dengan orang yang melihat atau melihat dan mendengarkan.Media gambar menjadi salah satu alternatif jenis media yang dapat dikembangkan untuk pembelajaran yang menyenangkan.

Pemilihan media bergambar juga didasarkan penggunaan media ini oleh Rosulullah dalam menyalurkan ilmu kepada para sahabat, penggunaan media ini dituangkan dalam sebuah Hadist Ibnu Hajar Atsqalani, t.t., Hadits ke 6054 dalam Muhammad Ramli (2015;138):

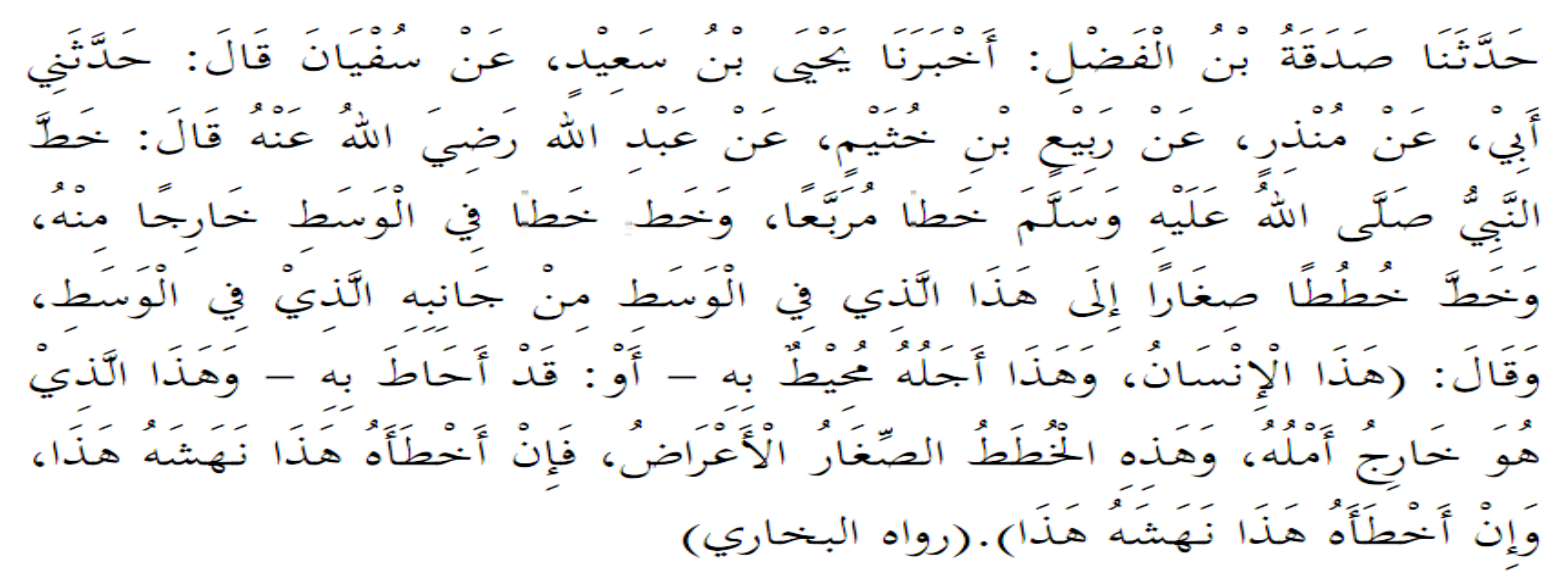

"Telah menceritakan pada kami Sodaqoh bin Fadhil, telah memberikan kabar kepadaku Yahya bin Sa'id dari Sofyan, beliau bersabda: Telah menceritakan kepadaku bapak ku dari Mundzir dari Robi' bin Khusein dan Abdullah R.A. Beliau bersabda: Nabi SAW pernah membuat garis (gambar) persegi empat dan membuat suatu garis lagi di tengahtengah sampai keluar dari batas (persegi empat), kemudian beliau membuat banyak garis kecil yang mengarah ke garis tengah dari sisi-sisi garis tepi, lalu beliau bersabda: Beginilah gambaran manusia. Garis persegi empat ini adalah ajal yang pasti bakal menimpanya, sedang garis yang keluar ini adalah angan-angannya, dan garis-garis kecil ini adalah berbagai cobaan dan musibah yang siap menghadangnya. Jika ia terbebas dari cobaan yang satu, pasti akan tertimpa cobaan lainnya, jika ia terbebas dari cobaan yang satunya lagi, pasti akan tertimpa cobaan lainnya lagi. (HR. Imam Bukhori) "

Nabi SAW menjelaskan garis lurus yang terdapat di dalam gambar adalah manusia, gambar empat persegi yang melingkarinya adalah ajalnya, satu garis lurus yang keluar melewati gambar merupakan harapan dan angan-angannya sementara garis-garis kecil yang ada di sekitar garis lurus dalam gambar adalah musibah yang selalu menghadang manusia dalam kehidupannya di dunia.

Selain itu kemasan isi buku juga harus diperhatikan, salah satunya adalah bentuk soal evaluasi yang menyenangkan sehingga menarik siswa belajar sambil bermain. Salah satu bentuk soal evaluasi yang menyenangkan adalah teka teki silang yang cukup digemari oleh semua kalangan. Kamus Pusat Pembinaan dan Pengembangan Bahasa(1994: 1023) mengungkapkan teka teki silang (TTS) adalah teka-teki huruf yang diisi dengan cara mengisi petak-petak atau kolom-kolom pada gambar yang telah disediakan. Sedangkan pengertian teka teki silang dari beberapa sumber dan pendapat menyatakan 
bahwa teka-teki silang adalah suatu permainan dengan cara mengisi kotak pada gambar yang disediakan yang dilengkapi dengan petunjuk untuk pengisiannya.

Melihat kebutuhan media dalam menunjang pendidikan biologi khususnya jaringan epitel maka perlu adanya Pengembangan Media Buku Bergambar Bertekstur Dilengkapi Teka-Teki Silang Sub Materi Jeringan Epitel Kelas XI SMA.

\section{METODE PENELITIAN}

Penelitian ini merupakan penelitian pengembangan (Research and Development), yaitu menurut adalah metode penelitian dimana hasil akhir dari penelitian tersebut berupa produk tertentu dan menguji keefektifan produk tersebut. Penelitian pengembangan suatu produk dipandang membutuhkan waktu yang lama atau bersifat longitudinal (bertahap) (Sugiyono, 2015:407).

Penelitian ini dilakukan guna menghasilkan produk berupa buku bergambar bertekstur yang dilengkapi dengan teka teki silang. Model pengembangan yang cocok dalam mengembangkan perangkat pembelajaran yaitu dengan menggunakan model pengembangan 4-D. Sivasailam Thiagarajan, Dotothy S. Semmel, dan Melvyn I. Semmel (1997) dalam Trianto (2010:189) menjelaskan mengenai tahapan pengembangan 4-D yaitu Define (Analisis Ujung Depan, Analisis Peserta Didik, Analisis Tugas, Analisis Konsep, Perumusan Tujuan Pembelajaran) dengan pengumpulan data berupa angket wawancara, angket tanggapan dan observasi. Design (Desain buku dan Materi media), design buku menggunakan Adobe Illustrator dan microsoft Word 2010. Develop (skala kecil dan skala besar), pengumpulan data uji skala kecil dengan meggunakan angket uji validasi ahli materi dan media, tanggapan guru, dan tanggapan siswa, uji skala besar mencakup data uji efektifitas menggunakan hasil rata-rata post test siswa dan keterbacaan media menggunakan angket tanggapan siswa, dan Disseminate atau diadaptasi menjadi 4-P yaitu pendefinisian, perancangan, pengembangan dan penyebaran.

Jenis data pada penelitian pengembangan adalah data kuantitatif dan data kualitatif, dimana data kuantitatif didapat dari skor angket dan evaluasi hasil belajar. Data kualitatif didapat dari tanggapan ahli media, ahli materi, guru serta tanggapan siswa terhadap media yang dikembangkan.

\section{HASIL DAN PEMBAHASAN}

Hasil dari analisis kebutuhan siswa mengenai media ajar, siswa membutuhkan media yang menampilkan gambaran bentuk jaringan secara benar dan menampilkan adanya gambar asli untuk mendukung pemahaman. Media yang dibutuhkan juga harus memudahkan siswa dalam memahami materi ajar dan menyenangkan dalam penggunaannya. Penyusunan karakteristik media juga disesuaikan dengan cara melakukan analisis peserta didik, ini dilakukan guna mengetahui minat dan karakter peserta didik mengenai media ajar. Analisis peserta didik menunjukan siswa justru lebih tertarik dan antusias dengan media yang memiliki kriteria sedikit tulisan, berwarna dan bentuk soal permainan yang menyenangkan. Hal tersebut selaras dengan penelitian yang dilakukan oleh Reda 
Taradipa dan Siswandari (2013) bahwa penggunaan kombinasi media yang sesuai akan meningkatkan minat belajar.

Tugas yang diberikan oleh guru merupakan tugas terstruktur dengan membebaskan siswa mencari sumber belajar dari buku atau internet. Pemberian tugas oleh guru biasanya berupa pencarian gambar dan materi yang akan dipelajari dalam pertemuan selanjutnya. Tugas dalam materi jaringan epitel biasanya merupakan pencarian gambar-gambar ilustrasi. Penyusunan media oleh peneliti menganalisi penggunaan konsep untuk menuangkan materi dalam media, dalam hal ini peneliti menggunakan silabus pelajaran Biologi K-13 yang digunakan oleh guru dengan indikator yang digunakan merupakan perincian konsep yang dilakukan oleh peneliti sesuai dengan Kompetensi Dasar yang telah diatur. Tujuan pembelajaran juga diatur dan di sesuaiakan dengan indikator pencapaian yang telah dirancang.

Kesimpulan yang dapat diambil dari tahapan defind yang telah dilakukan adalah media yang dikembangkan merupakan media yang memiliki karakteristik banyak gambar, sedikit tulisan dan banyak warna. Media yang diharapkan juga mampu memudahkan dalam memahami materi, menyenangkan dalam penggunaanny, memiliki konsep dan sumber yang jelas, mampu mencapai tujuan pembelajaran serta dapat digunakan dalam kegiatan praktikum. Perancangan media dengan karakter tersebut sesuai dengan Undang-undang No. 20 pasal 40 ayat 2 berbunyi "guru dan tenaga kependidikan berkewajiban menciptakan suasana pendidikan yang bermakna, menyenangkan, kreatif, dinamis, dan dialogis" (Kemenag, 2003). Menciptakan suasana pendidikan yang menyenangkan harus di dukung salah satunya dengan penggunaan media yang menarik dan menyenangkan agar tercipta pembelajaran yang bermakna dan menyenangkan.

Tindak lanjut tahap define yang telah dilakukan adalah melakukan tahap design sesuai dengan data dan kebutuhan yang telah diperoleh dalam tahap define. Tahap design media dilakukan dengan beberapa tahapan antara lain, tahapan pertama adalah pemilihan media, dilakukan dengan pemilihan aplikasi yang digunakan, dalam pembuatan media digunakan media Microsoft Word 2010 dan dalam pembuatan gambar jaringan epitel digunakan aplikasi Adobe Ilustrator dengan bantuan ahli. Tahapan kedua merupakan pemilihan format, dalam tahap ini dipilih format buku mulai dari judul, daftar isi, materi, evaluasi teka teki silang, evaluasi singkat, daftar pustaka dan profil penulis. Pemilihan format dilakukan agar memudahkan dalam penggunaan media dalam pembelajaran. Tahap ketiga adalah rancangan isi, tahap ini merupakan tahapan penataan materi inti dalam media.

Media yang telah selesai dirancang dalam tahap design selanjutnya akan masuk dalam tahap Development yang merupakan tahap pengembangan media secara lebih lanjut, pada tahap ini media akan melalui uji valiadasi oleh para ahli (ahli materi dan ahli media dan guru kelas) dan uji lapangan.

Uji validasi yang pertama adalah ahli materi, dalam tahapan uji materi ahli akan menilai kesesuaian konsep dalam materi, penilaian akan dilakukan dengan menggunakan angket penilaian dengan hasil penilaian yang didapatkan media termasuk dalam kategori sangat baik dengan presentase 
90,9\%. Validasi oleh ahli materi dilakukan sebanyak dua kali, validasi pertama dengan pengisian angket dan validasi ke dua dengan koreksi revisi. Masukan yang didapatkan dari ahli materi antara lain penyesuain keterangan gambar agar tidak terjadinya kesalahan konsep dan revisi gambar yang kurang relevan dengan materi. Kelebihan media menurut ahli media antara lain tampilan media yang tidak membosankan dan bagian tekstur yang memudahkan dalam penggunaan media.

Tahapan validasi selanjutnya oleh ahli media, ahli media akan menilai dan memberikan saran tentang tampilan media yang dikembangkan. Penilaian oleh ahli menggunakan angket penilaian dengan hasil penilaian sebesar 85,5\% dengan kategori sangat baik/layak. Validasi dilakukan sebanyak dua kali, dengan validasi ke dua berupa penyerahan hasil revisi kepada ahli media. Masukan yang didapatkan dalam penilaian ahli media antara lain capaian indikator media yang perlu di jabarkan lagi, sedangkan kelebihan media menurut ahli madia antara lain gambar yang jelas dan mudah dibaca.

Validasi selanjutnya merupakan validasi oleh guru. Validasi dilakukan dengan pengisian angket penilaian dan masukan guru mengenai media. Hasil penilaian media oleh guru mendapatkan presentase 98,46\% dengan kategori sangat baik/layak. Masukan yang didapatkan antara lain gambar media yang harus disesuaikan kembali, sedangkan kelebihan media adalah dapat memberikan gambaran yang lebih nyata. Hasil penilaian oleh ahli dan guru dituangkan dalam grafik berikut :

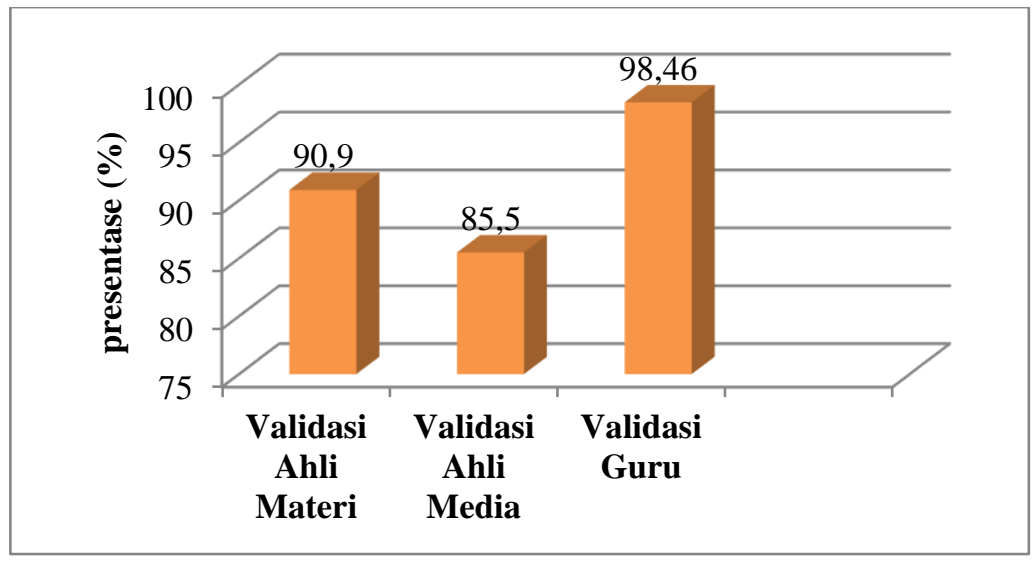

Gambar 1. Grafik Penilaian Ahli dan Guru

Tahap Development selanjutnya merupakan uji lapangan, penelitian dilakukan uji lapangan terbatas/kelas kecil dan uji lapangan luas/kelas besar. Uji lapangan terbatas dilakukan dengan pemberian angket penilaian kepada 18 siswa tentang media, uji lapangan kecil bertujuan untuk mengetahui kelayakan media dari sudut pandang penilaian siswa, penilaian dilakukan dengan memberikan media pada siswa untuk dilihat dan dinilai kelayakannya. Hasil penilaian uji lapangan terbatas media mendapatkan presentase $87,59 \%$ dengan kategori sangat layak/sangat baik. Sebanyak 93,3\% siswa tertarik dengan media yang dikembangkan, hal ini merupakan respon yang baik dari siswa untuk perkembangan selanjutnya. 
Penggunaan ciri khas tekstur dalam media memperoleh presentase ketertarikan siswa sebesar 87,7\% dengan kategori sangat baik dalam mendapatkan daya tarik siswa terhadap media. Komponen media yang tersusun dari segi materi yang ringkas, padat isi, dan tidak membuat jenuh siswa mendapatkan presentase sebanyak $88,8 \%$. Soal evalusi berupa permaninan dan evalusi singkat berhasil menarik minat siswa, mendapatkan presentase $78,8 \%$ dengan kategori baik. Meningkatnya minat dan ketertarikan siswa dalam uji ini sesuai dengan pernyataan Hamalik (1968) dalam Tejo Nurseto (2011) pemanfaatan media pembelajaran dapat membangkitkan minat siswa, meningkatkan motivasi dan kegiatan pembelajaran yang berlangsung dan dapat berpengaruh pada psikologis siswa. Masukan yang didapatkan dalam uji kelayakan siswa adalah penggunaan warna cover yang cerah dan keterangan gambar yang kurang jelas. Hasil uji lapangan terbatas dituangkan dalam grafik berikut :

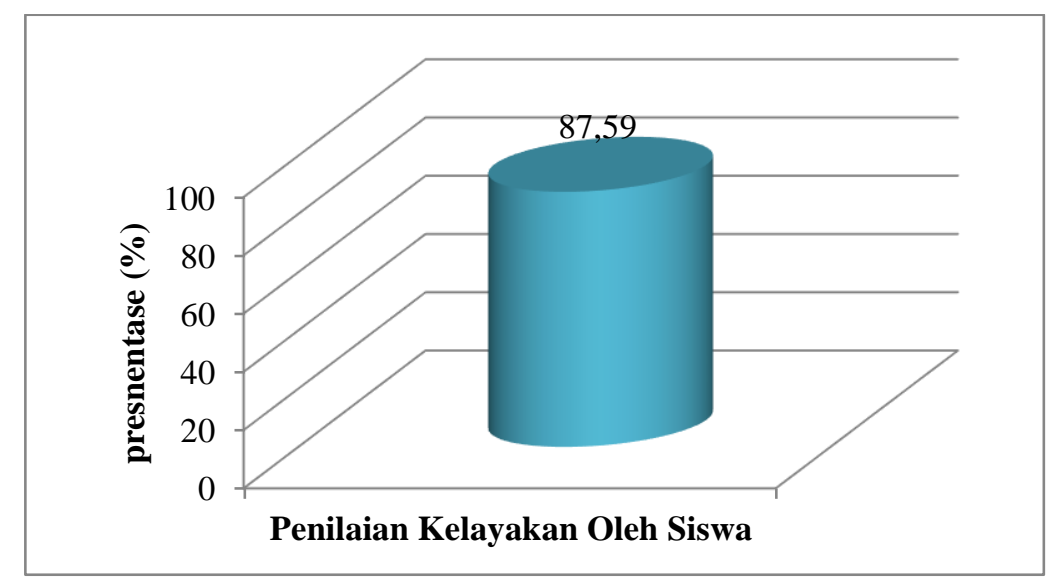

Gambar 2 Grafik Uji Lapangan Terbatas.

Uji lapangan luas/skala besar dilakukan guna menguji penggunaan media didalam kelas, uji coba media yang diambil adalah uji efektifitas penggunaan media dengan membandingkan rata-rata nilai siswa kontrol dan siswa uji coba. Efektifitas diartikan keberhasilan (tentang usaha, tindakan) (KBBI Online, 2016). Merujuk pada pengertian tersebut dapat disimpulkan afektivitas penggunaan media adalah keberhasilan pencapaian tujuan belajar setelah digunakannya media.. Rata-rata nilai siswa dituangkan dalam grafik berikut :

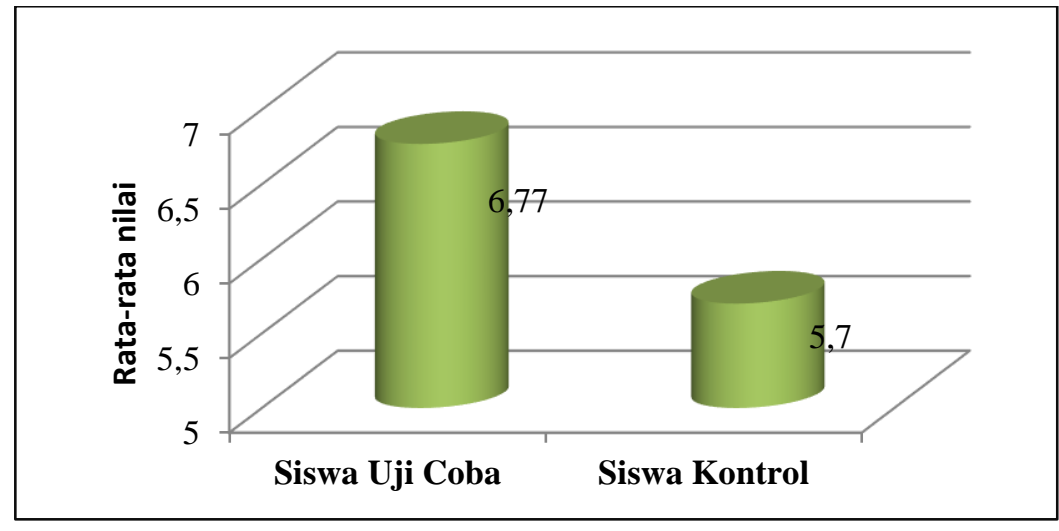

Gambar 3. Grafik Hasil Nilai Rata-Rata Siswa 
Gambar 3 menunjukkan hasil nilai rata-rata siswa uji coba dan siswa kontrol yang dapat dikatakan cukup efektif dalam meningkatkan nilai siswa. Menurut Sudjana dan Rifai (2002) dalam Yuyus Suherman (2008) salah satu manfaat media pembelajaran adalah menjelaskan makna materi atau bahan pelajaran sehingga akan lebih mudah difahami oleh siswa sehingga memungkinkan untuk menguasai dan mencapai tujuan belajar. Hasil perbandingan rata-rata siswa pada gambar 4.17 selaras dengan manfaat media yang telah diungkapkan, grafik menunjukkan tujuan pembelajaran lebih tercapai dengan menggunakan media yang dikembangkan.

Hasil rata-rata menunjukkan nilai kedua kelas percobaan masih berada di bawah KKM (Kriteria Ketuntasan Minimum) hal ini dikarenakan peneliti bukan melihat dari tingkat ketuntasan namun melihat pada nilai rata-rata yang lebih tinggi antara siswa kontrol dan kelas uji coba. Kendala yang dihadapi saat dilakukannya pembelajaran juga mempengaruhi nilai siswa, salah satu kendala yang dihadapi dalam pengambilan hasil evaluasi adalah kurang kondusifnya jam mengajar saat dilakukannya penelitian, pengajaran dan pengambilan hasil evaluasi di kelas hanya dilakukan selama satu jam pelajaran (45 menit) di jam ke empat pukul 12:45 dengan cakupan materi yang cukup banyak. Selaras dengan hal ini Indah Lestari (2013) dalam penelitiannya mengungkapkan adanya pengaruh yang signifikan antara waktu belajar terhadap hasil belajar yang diperoleh, hasil penelitian ini menunjukkan nilai siswa cenderung lebih meningkat jika pembelajaran dilakukan di pagi hari.

Tahapan uji skala luas/besar berikutnya adalah uji keterbacaan media setelah digunakan dalam pembelajaran kelas, dalam uji ini peneliti memberikan angket yang akan diisi oleh siswa uji coba terkait keterbacaan media yang telah digunakan. Hasil uji keterbacaan oleh siswa uji dituangkan dalam grafik berikut :

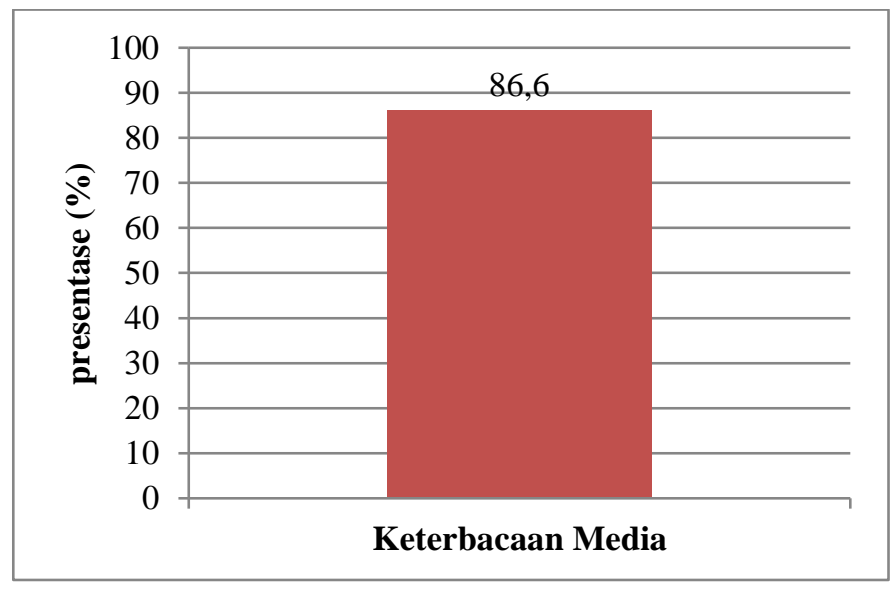

Gambar 4. Grafik Hasil Keterbacaan Media

Gambar 4 menunjukkan hasil keterbacaan media sebesar 86,6\% dengan kategori sangat baik. Penggunaan media dalam pembelajaran berhasim meningkatkan minat belajar siswa pada materi jaringan epitel dengan presentase sebesar $86,6 \%$, bentuk tekstur yang menjadi ciri khas yang dikembangkan dalam media terbukti mampu memudahkan siswa dalam memahami materi dengan presentase $87,7 \%$ atau sangat baik. Pemilihan soal evaluasi berupa permainan dalam media untuk 
mengurangi tingkat kebosanan dan kejenuhan siswa selama pembelajaran mendapatkan presentase $81,1 \%$ dengan kategori sangat baik, pendukung lain dalam penyajian materi yang terdapat dalam media adalah adanya gambar-gambar preparat asli yang memudahkan siswa dalam memahami dan membayangkan bentuk nyata jaringan epitel dalam tubuh, dalam kategori ini mendapatkan presentase $82,2 \%$ dengan kategori sangat baik. Hasil tersebut menunjukan keberhasilan penggunaan media dalam meningkatkan minat, motivasi, dan kemudahan dalam memahami pembelajaran.

Hasil penelitian menunjukkan media yang dikembangkan dapat dikatakan layak digunakan dan berhasil dalam meningkatkan minat, motivasi belajar, menurunkan tingkat kebosanan dalam kelas dan meningkatkan nilai siswa.

\section{KESIMPULAN}

Buku bergambar bertekstur dilengkapi dengan teka teki silang sebagai media pembelajaran Biologi sub materi jaringan epitel kelas XI semester 1 layak digunakan dalam pembelajaran. Kelayakan diperoleh dari hasil uji validasi ahli materi 90,9\% dengan kategori sangat baik, hasil uji validasi ahli media 85,5\% dengan kategori sangat baik, hasil uji guru 98,48\% dengan kategori sangat baik, hasil uji coba kelas kecil tentang penilaian kelayakan oleh siswa 87,59\% dengan kategori sangat baik, hasil uji coba kelas besar mengenai efektifitas penggunaan media dengan hasil rata-rata siswa uji coba 6,77 dan siswa kontrol 5,70 sehingga dapat dikatakan cukup efektif untuk meningkatkan nilai siswa dan uji keterbacaan media selama penggunaan $86,1 \%$ dengan kategori sangat baik.

\section{DAFTAR PUSTAKA}

AECT . 1997. The Definition of Edducational Technology. Washington. Assosiasion of Educational and Communication Teachnology

Arsyad Azhar. 2009. Media Pembelajaran. Jakarta. Rajawali Press.

Ferry, D. (2019). Peningkatan Hasil Belajar dan Keaktifan Mahasiswa Melalui Strategi Pembelajaran Peta Konsep Pada Mata Kuliah Evolusi. Journal on Education, 1(4), 809-816. Retrieved from http://www.jonedu.org/index.php/joe/article/view/249

Hamalik Oemar. 1994. Media Pendidikan (cetakan ke-7). Bandung. Penerbit PT Citra Aditya Bakti.

Joneta Witabora. 2012. Peran dan Perkembangan Ilustrasi. HUMANIORA Vol.3 No.2 Oktober 2012: 659-667

Kemenag. 2003. UNDANG-UNDANG REPUBLIK INDONESIA NOMOR 20 TAHUN 2003 TENTANG SISTEM PENDIDIKAN NASIONAL.

Kemendikbud. 2016. Kamus Besar Bahasa Indonesia (KBBI) Versi Online/daring (dalam jaringan). Tersedia http://kbbi.web.id/ diakses pada 17 November 2016.

Lestari Indah. 2013. Pengaruh Waktu Belajar dan Minat Belajar Terhadap Hasil Belajar Matematika. Jurnal Formatif 3 (2) : 115-125. 
Nurseto Tejo. 2011. Membuat Media Pembelajaran yang menarik. Fakultas Ekonomi Universitas Negeri Yogyakarta. Jurnal Pendidikan dan Ekonomi Volume 8 No 1, april 2011.

Ramli Muhammad. 2015. Media Pembelajaran Dalam Perspektif Al-Qur'an Dan Al-Hadits. Itihad Jurnal Kopertais Wilayah XI Kalimantan. Volume 13 No. 23 April 2015

Santoso Hari. 2008. Membangun Minat Baca Anak Usia Dini Melalui Penyediaan Buku Bergambar. UPT Perpustakaan Universitas Negeri Malang

Sitepu. 2014. Pengembangan Sumber Belajar. Jakarta. Rajawali Press.

Sugiyono. 2015. Metode Penelitian dan Pendekatan Kuantitatif, Kualitatif, dan R\&D cetakan ke 21. Bandung: Alfabeta

Suherman Yuyus. 2008. Pengembangan Media Pembelajaran Bagi ABK. Makalah Diklat profesi guru PLB X wilayah Jawa Barat Bumi Makmur, Lembang Bandung 2008. Tersedia file.upi.edu

Taradipa Reda, Siswandari. 2013. Pengaruh Kombinasi Media Pembelajaran Terhadap Minat Belajar Mahasiswa Pada Mata Kuliah Teknologi Pembelajaran Akuntansi. Jurusan Ekonomi FKIP Universitas Negeri Surakarta. vol.2 No.1 (2013).

Tim Penyusun Kamus Pusat Pembinaan dan Pengembangan Bahasa.1994. Kamus Besar Bahasa Indonesia. Jakarta: Balai Pustaka.

Trianto. 2010. Mendesain Model Pembelajaran Inovatif-Progresif. Jakarta: Kencana Prenada Media Group 